\title{
Dimensions of Investment Behavior: A Case of Kids Higher Education
}

\author{
NS Bohra, Girish Lakhera, Poonam Verma
}

\begin{abstract}
Making excellent investments decisions is difficult for most of the peoples, we all have hopes and fears regarding our investments, yet unknown to us, these same hopes and fears can damage our investment performance. Neuroscience research demonstrates how these emotions originate in the brain's center of emotional processing, the limbic system, in various financial situations. We can learn to identify these emotional disturbances in our financial reasoning. Distorted reasoning is often characterized by intense feeling. However, unless we make a conscious effort to become aware of our feelings, we can easily succumb to their destructive tendencies, based on this understanding researchers in this study is focusing on some of few core issues, which are main constraints at the time of basic financial planning of an individual. These issues are why do some people take a lot of risk in financial and other people don't? Why do some people save very little for retirement and some save a lot more? Why do some people become overconfident when they invest? In this study, education is treated as a form of investment and the focus of the study is to understand individual's investment behavior at the time of investing in child higher education.
\end{abstract}

Keyword: Investment Behavior, Higher Education

\section{INTRODUCTION}

Neurofinance is all about to be smart regarding our investment. It is an innovative concept about the investment, it is an emerging field of investigation that merger knowledge from neuroscience and finance with regards to behavioral finance and neuroeconomics. The field of decision making is largely concerned with the processes by which individual's make a single choice from among many options. Neurofinance has been defined as the study and application of neuroscience to investment activity. Investment activity in this regard includes evaluating, buying, or selling securities. Neuroscience research examines how the brain perceives, processes, evaluates, understands, and decides based on input from the outside world. It is important to understand that neurofinance is not simply interested in mapping out parts of the brain. Instead, by looking at how the brain reacts during various investment activities. The investor has a different psychology due to various factors like demographic, education level, age, gender, income etc which affects the investment behavior of the investor, for instance a person between the age group of 25 to 30 years always prefers more risky investment avenue whereas person above 30 years with a family dependability prefers less risky investment avenue with a constant rate of return.

Revised Manuscript Received on October 02, 2019.

Dr. NS Bohra, Associate Professor, Department of Management Studies, Graphic Era Deemed to be University, Dehradun (Uttarakhand), India. E-mail: nsbohra.mba@geu.ac.in

Mr. Girish Lakhera, Asst Professor and Research Scholar, Department of Management Studies, Graphic Era Deemed to be University, Dehradun (Uttarakhand), India. E-mail: girishlakhera@geu.ac.in

Ms. Poonam Verma, Graphic Era Hill University, Dehradun (Uttarakhand), India
Scientists still have not uncovered the full extent of what a brain can do, but to a large extent all the financial decision is depends on brain. Similarly, rural or urban background of individuals, availability of information, accessibility of avenues and investment companies also influence individuals in developing their perceptions towards investment. Neurofinance focused on how people make risky decisions by focusing on the workings of the brain. The goals of neurofinance are to identify the psychological inputs that impact trading behavior and then connect these traits to trading success or failure.

\section{REVIEW OF LITERATURE}

Shalini Kalra Sahi, (2012) explains neurofinance is a very young discipline. It tries to relate the brain processes to the investment behaviour. Most of the researches in the domain of neurofinance focus on trading behaviour. It would be interesting to explore the workings of the brain for other investment behaviours too like personal financial planning decisions, etc. Frydman, Cary D. (2012) investigate two trading patterns, the disposition effect and the repurchase effect, are unlikely driven by standard rational models of trading, and alternative theories of their causes are difficult to test using only data from the field, or data from behavioral laboratory experiments.In order to better understand the causes of the disposition effect and the repurchase effect, he use neural data, data collected from functional magnetic resonance imaging (fMRI) along with trading data to construct empirical tests of different theories.Russell N.James III (2011), presents findings from neuroscience, neuro-finance, neuro-economics, behavioral finance, and behavioral economics in the context of a twosystem model of human decision making, labeled as the "rider" and the "elephant". The rational "rider" system is characterized by overconfidence and deficiencies in speed and endurance. The emotional "elephant" system is characterized by time preference myopia, emotional marker processing, and loss aversion. Application of this neural model of financial decision-making results in a variety of effective and practical suggestions for financial planners. Sapra,steven G (2009), his findings from neuroeconomics to postulate a relationship between neural mechanisms in the human brain, and financial market anomalies such as overreaction and herd behavior. Secondly, "Stochastic Risk Aversion, Behavioral Over-Reaction, and the Role of Informed Investors", describes a mathematical model of 'behavioral investors', who are characterized by random risk aversion shocks, and 'rational arbitrageurs', who attempt to exploit the over-reaction of the former cohort. 


\section{Dimensions of Investment Behavior: A Case of Kids Higher Education}

I show that the presence of arbitrageurs results in a more stable market environment, less susceptible to market crashes. In the absence of 'arbs', markets are unnecessarily volatile and unpredictable. Finally, "Genes and Traders", is a genetics paper, where I test to see if financial market traders have two particular gene mutations associated with clarity of thought. Doya and Corrado (2007) review both the development of computational models capable of capturing the dynamics of individual choice and specific cases in which the internal variables of these models have provided the basis for extracting the correlates of subjective choice from the electrophysiological data of primates. In this case, it is the dynamic integration of the computational, neural, and behavioral data that has provided insight into the subjective variables controlling choice.Knutson and Bossaerts (2007) describe the emerging neurofinance approach to decision making but also examine the specific application of models of decision making under risk and the behavioral tasks that have been developed to examine financial decision processes in human subjects together with their neural correlates using fMRI . Christoph Merkle, (2007), explores the influences of emotions on human decision making, especially in context of finance. It reviews the psychological, neuroscientific and neuroeconomic evidence about the topic and shows which applications these insights have found in behavioral finance and the new subject of neurofinance. K.C. Tseng (2006), said the behavioral finance, evolutionary finance, and neurofinance are challenging the traditional finance. Whether the financial markets, in particular the stock markets, are efficient or not and whether market participants are rational or not, depend to a large extent on the ways people look at the markets. They look at exactly the same empirical evidence or findings, but they may interpret the observations quite differently. People are yet different biologically, genetically, in education and training, in experience, in opportunities, and many other aspects. Financial market participants and researchers have diversified background in education, training, experience, investment objectives, available information, time constraint, capability of analyzing and processing available data, and the ability to predict the future uncertain conditions. Camelia M. Kuhnen and Brian Knutson (2005), Studies Neurofinance could also be used to train and test traders one's brain activation in the nucleus accumbens predicts person's risk-taking willing. So some devices can be used in recruiting new traders and investors. But this method should only be kind of reference since a good trader or investor needs other important abilities.Neurofinance implements research methods which are totally different from the traditional ones. David Edwards ,(2004), finds that neurofinancial theory holds that our inability to behave rationally is rooted in our psychophysiology. Because neurofinance is based on the assumption that individuals have varying psychophysiological make-ups, which in turn play a strong role in both their ability to make rational decisions and in their success as financial market operators, it represents a contrary approach to that of the efficient market hypothesis ("EMH"). EMH, the theory upon which most of modern finance is based, as well as its antecedent, utility theory, contain the implicit precondition that humans generally act out of rational self-interest, and will behave accordingly when faced with economic decisions. In other words, that people will make the most rational and efficient economic choice no matter the situation or conditions. Paul W Glimcher, Aldo Rustichini (2004), states economics, psychology, and neuroscience are converging today into a single, unified discipline with the ultimate aim of providing a single, general theory of human behavior. This is the emerging field of neuroeconomics in which consilience, the accordance of two or more inductions drawn from different groups of phenomena, seems to be operating. Economists and psychologists are providing rich conceptual tools for understanding and modeling behavior, while neurobiologists provide tools for the study of mechanism. The goal of this discipline is thus to understand the processes that connect sensation and action by revealing the neurobiological mechanisms by which decisions are made. This review describes recent developments in neuroeconomics from both behavioral and biological perspectives. Nicholas Barberis, (2002), states that behavioral finance argues that some financial phenomena can plausibly be understood using models in which some agents are not fully rational. The field has two building blocks: limits to arbitrage, which argues that it can be difficult for rational traders to undo the dislocations caused by less rational traders; and psychology, which catalogues the kinds of deviations from full rationality we might expect to see. We discuss these two topics, and then present a number of behavioral finance applications: to the aggregate stock market, to the crosssection of average returns, to individual trading behavior, and to corporate finance. We close by assessing progress in the field and speculating about its future course

\section{DATA ANALYSIS AND INTERPRETATION}

It has been observed in this study that the investment objective for majority of people is the steady returns with strong protection of principal money. It reflects the psychology that they want their investment to be safe, they do not want to lose their money while $72 \%$ of people do not consider high return with low protection of principal money as their investment objective. $56 \%$ people give the natural response for high return with steady protection of principal money as their investment objective.

The source of money for future investment is saving for $70 \%$ of the investors. They utilize their savings for investment purpose. On the other hand 56\% investors uses return from earlier investment for future investment. $56 \%$ individuals are not considering that taking loan from the bank for future investment can be a source of money.

$74 \%$ individuals considers that their stage of job plays very crucial role while they make any investment decision if a person is employed in a safe and a good salary job then he always makes the investment in that avenue which gives him high returns with relatively high risk and 50\% people consider that the stage of life can also be a important factor for investment because if you are matured enough then you always make investment in that options which is relatively less risky because at that time he has family dependability. 
Advice of finance expert is vital for selecting Investment Avenue because finance expert knows the technicalities of various investment decisions; they know how to invest, where to invest and how the amount of investment should be diversified for minimizing the risk. $74 \%$ investors in Dehradun take the advice of financial expert while they make any financial decision. Investor's intellectual capabilities influence the selection of a particular investment avenue. 60\% people in Dehradun consider this factor as important for selecting Investment Avenue. If a person is capable enough that he can analyze the different investment avenue and able to match with his life goals then he makes sound financial decision and his entire life goal can be met. Advice of the family is also an important factor for selecting Investment Avenue because they are familiar with each and every condition of the investor, an investor's life goals, his limitation and what resources are available to him.

They feel that the advice of friends and college does not play a vital role for making financial decision. $30 \%$ people observed that emotions does influence the financial decision because it is related to psychology and neurology. While $64 \%$ people are dissatisfied emotional influence is caused by hormonal changes.

Education helps in building the psychology of the investor afterwards the role of past experience comes in picture. An individual selects a college for professional studies on the basis of placement record of the college. $84 \%$ individuals take admission in that college which has a good placement record from past so many years. $78 \%$ individuals take admission on the basis of quality of education that a college provides to its students. Both the reputation of college and capability of student is responsible for he success and failure of any investment decision made in professional education of a child.

Now-a-days $90 \%$ individuals feel that investment in professional education of a child is necessary because it helps in securing his or her future. A person can only try for a job when he has some professional degree otherwise he or she is not eligible for the job. Holding professional degree gives some sense of future security.

Other aspect is that the bank will consider the women as less efficient for repayment of loan because there are some restrictions levied on them. And 70\% people do not consider that the women are less competent. They feel that women are also competent and capable for repaying the loan.

\section{CONCLUSION}

The study reveals that the individuals make financial decisions in different investment avenue in order to satisfy their financial, psychological and social needs. The research is done with 50 people in Dehradun city and I found that the investor's basic objective behind any investment is steady return with strong protection of principal money. An individual decision is influenced by many factors viz their emotional status, stage of their job, advice of finance expert and their intellectual capabilities.

Every investor wants that his or her investment would be safe and they will earn a good return on his investment. Investment made in professional education is meant for future security of a child and a student takes admission on the basis of placement record of the college. Finally, neurofinance is more practical approach towards investment. It helps in better understanding of investment behavior which in turn helps in making sound financial decision.

\section{REFERENCE}

1. Gounden, A. N. (1967). Investment in education in India. Journal of Human Resources, 347-358.

2. Shalini Kalra Sahi "Neurofinance and investment behaviour", Studies in Economics and Finance, Vol. 29 Iss: 4, 2012, pp.246 - 267

3. MostafaSadeghnia, Abdolhamidhooshmand $\square \square$, Habibniko $\square \square \square$ "Behavioral Finance and NeuroFinance and Research Conducted in This Area" Interdisciplinary Journal of Contemporary Research in Business, April 2013 Vol 4, No 12, pp.793 - 799 [Online] Available at http://journal-archieves31.webs.com/793-801.pdf

4. Mohammed Z. Shariff, Jamal Al-Khasawneh, Musab Al-Mutawa "Risk and Reward: A Neurofinance Perspective" International Review of Business Research Papers Vol. 8. No.6. September 2012. pp. $126 \quad-\quad 133 . \quad$ [Online] Available at http://www.bizresearchpapers.com/8.\%20Shariff.pdf

5. Balleine W. Bernard - "The Neural Basis of Choice and Decision Making", The Journal of Neuroscience, August, 1. 2007, 27(31): pp8159-8160

6. Kuhnen, Camelia M., and Brian Knutson. "The neural basis of financial risk taking." Neuron 47.5 (2005): pp763-770.

7. K.C. Tseng "Behavioral Finance, Bounded Rationality, NeuroFinance, and Traditional Finance" Investment Management and Financial Innovations, Volume 3, Issue 4, 2006, pp 7-18 [Online] Available at http://businessperspectives.org/journals_free/imfi/2006/imfi_en_2006 _04_Tseng.pdf 
Annexure - 1

1. What should be objectives of investments?

\begin{tabular}{|c|c|c|c|c|}
\hline & Satisfied & Natural & Dissatisfied & No Answer \\
\hline A. Protection of principal money & 30 & 18 & 2 & 0 \\
\hline $\begin{array}{l}\text { B. Steady returns with strong protection of } \\
\text { principal money }\end{array}$ & 38 & 11 & 1 & 0 \\
\hline $\begin{array}{l}\text { C. High return with steady protection of } \\
\text { principal money }\end{array}$ & 15 & 28 & 7 & 0 \\
\hline $\begin{array}{l}\text { D. High return with low protection of } \\
\text { principal money }\end{array}$ & 5 & 9 & 36 & 0 \\
\hline
\end{tabular}

2. What should be the idle sources of money for future investment?
A. Savings
$35 \quad 15$
B. Returns from earlier investment
28
15
C. A certain portion of monthly salary
22
24
D. Loan taken from another source
3
13

$\begin{array}{cc}0 & 0 \\ 2 & 2 \\ 3 & 1 \\ 26 & 8\end{array}$

8

3. What factors play important role in your investments?
A. Stages of your jobs
37 10
B. Stage of your life $25 \quad 20$
C. Children education pressure
23
D. Income tax pressure
21
E. Retirement fear
14
26

$\begin{array}{ll}2 & 1 \\ 4 & 1 \\ 7 & 1 \\ 6 & 0 \\ 6 & 4\end{array}$

4. Which factor influences you while choosing investment avenues?
A. Your own intellectual capabilities
$30 \quad 15$
B. Advise of family members
22
C. Advices of finance expert
37
D. Advice of friends and colleges

$23 \quad 4$

7

5. Does an emotion influence the financial decision?
A. Because it is related to psychology \& neurology
$15 \quad 25$
0

15
B. Caused by hormonal changes
C. Caused by automatic nervous system
5
12
6. Which factor helps in building the psychology of the investor?
A. Surrounding
29
42
34
C. Past experience
15

8


7. On the basis of what factors an individual selects a college for professional studies?
A. Past record of college
33
17
B. Word of mouth communication
15
23
C. Placement record
42
8
D. Quality of education
39
10

$\begin{array}{cc}0 & 0 \\ 11 & 1 \\ 0 & 0 \\ 1 & 0\end{array}$

8. Do you consider the investment in professional education is safe?
A. Depends on college
32
11
$7 \quad 0$
B. Depends on child's capability
32
17
C. Depends on availability of job
27
20
D. Depends on seriousness of a child
24
18
0
2
7

9. Why there is a need to invest in the professional education of a child?
A. Future security
45
5
0
0
B. Necessity of the time
$22 \quad 26$
2
C. Morale responsibility
20
18
10
2

10. Why the bank will consider women as less efficient for the repayment of the loan?
A. Dependability on others
22
21
6
B. Restrictions levied on them
23
19
C. Incapable of taking risk
9
16
6
2
D. Less competent
5
4 